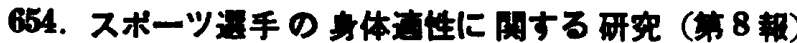

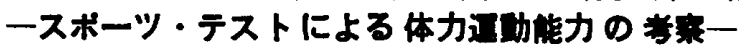
（その7）因子分析法としての成分分析法の理成的落 萧

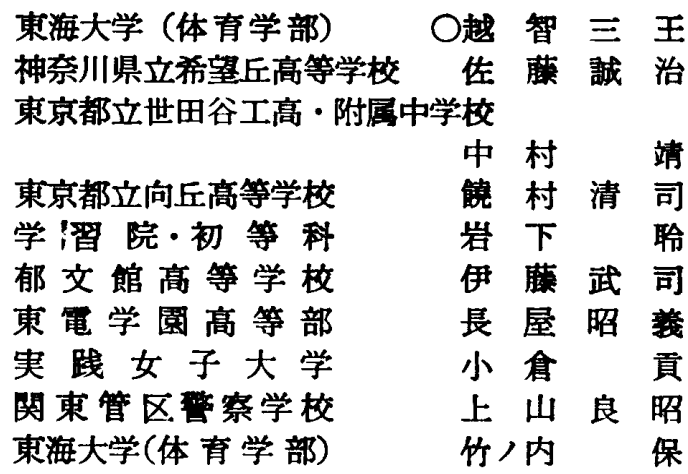

(1) 网昌提迊

自然現象・社会現象の湘定に際しては，多くの変化し た测定値が得られる．体有测定における形態・機能・運 轵能力などの測定においては測定值の変動はさらに激し い.このような多変量の解析法については計算労力が非 常に多く必要とされるので，体育界ことにわが国体育界 では活用されないままになつているが，取近電子計算機 の発達活用により活用のきさしと見とおしができるよう になつたので、筆者等むこの方法を用いて，因子の究明 にあたることにした。

(2) 研究目的

最近盛んに実施されはじめたスボーッ・テストなどを
はじめとする体力テスト項目の因子が，如何なる因子螎 造（質的），因子負荷县をるつるのなのかを究明するこ とは，最少のテスト項目で取大人数の測定に貢献できる ことは明らかである.そこでテストに内包する因子を探 究する方法として因子分析法を用いるべきであるが，む しろ第一段階では（主）成分（分）分析法によつて質的 解明をし，引続き第二段階で，いわゆる因子分析に上り 量的解析をした方がよいことが理解されたので，今回は まず（主）成分分析法を用いることによつて筫的解析を することに止めた。

\section{[3] 基本标念}

1940 年代に公刊された L.L. Thurstone の菜成書か ら心理学・社会学・教育学・生物学などの分野に活用さ れているよらなところから，各測定特性間に内在する因 子は「なにか?」を教するに止まらず,ささらに一歩深 く解析すへく，測定変量内部に内在する因子の「方方わ ウあいの程度」または因子相互の「はたららまがすの強さ ら程度」を解明する方法として開発されたものが成分 （因）分析法であるという.

〔4]方法と結果の考腺

演題 No. 430〜435 に述べられているので省略する.

(5) 結诮

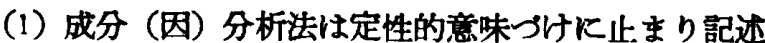
的である。

（2）ただし数字の混乱による解积が防止できる点で有 効である

（3）引続き因子分析法によつて量的解析が必要.
655. 定時制高校生の体力・通糼能力の現状とクラフ活 功についての一考莱

東京都立両国高等学校

$\begin{array}{ccc} & \text { O元 } & \text { 和臣, 飯田 穎男 } \\ \text { 日 本 大学 } & \text { 吉本 俊明, 并上 俊孝 } \\ \text { 帝 京 大 学 } & & \text { 中 尾 敬 治 } \\ \text { 日本橋女学館 } & \text { 三宅章 介 }\end{array}$

目的と方法 青少年の健康を增進 し，效率的な身体 を育成する事は我々の责務である，文部省の体力・運動 能力調查報告書によると，1，2 を除いては全日制課程と 定時制課程とを比較した場合，全般的にその差が著しい 事が示されている．第 17 回大会に於ては，実施条件の 相違として身長日差及び自覚疲労症状調查表を併せて発 表した．今回は同じくスポーッテストを全校生徒に実施 して 50 名無作意抽出し， 41 年度と此較検討すると共に 生活の実態及びクラブ活動参加の状態を把握し，生徒の 体力・運動能力の発達を促進するよらな運動・補強運動 のプログラム作製の基盤として研究したるのである.

結果と帣寀 本校に於ては愁垂の 18 才を除いて体力 ・運動能力雨テスト共昨年より向上のあとがみられる. 文部省調查報告書によると全日制に比して定時制課程で は早く固くなること, 運動能力の劣る事が示されてい
3. 41 年度に於ては本校もその佰向にあつたが，本年は $1500 \mathrm{~m}$ 走・伏卧上体そらし・立位体前屈の 全日制課程 に劣つていた種目に向上のあとがみられる，又，本校 の体力・運動能力は全日制銅程 と比㠇して $16 \cdot 17$ 才の 50m，17 才の愳垂を除いては優ぐれている．これは年 々向上している体力・運動能力のはかに (1) 本年度は琞 明が完備し湘定条件が違つた．（3)昨年度のテストの実 態を生徒にしらせ柔㜞性の運動をとり入れた。（〕 照明 が完備し屋外授業及びクラブ活動も活淡化した，等も向 上の原因になつていると思われる．運動クラプ所属数の 增加傎向は，定時制課程では施設拡充は体有活動加 の要因である．全日制・定時制生徒 150 名の調查結果 によると，全日制と定時制で睡眠時間」6時間以下 $32.8 \%$ と $48.3 \%$ でひんぱんに運動したい」59.3\% と $65 \%$ ，「運動不足をよく感じる」者は 40\%と $45 \%$ で現 代青年の睡眠や運動不足を如実に現わしている. 一方 学校の余嘬時間は「教室で過ごす」者全日制 $68.7 \%$, 定時制 $66.7 \%$ でグランドの利用率は低い，之等の 事よ り，体力・運動能力の向上の為めには施設・設備の充実 と共に余㖊利用には進んで運動に至加する態度を有成 し，青年の実態を把握し，これらに即応した指萃は切実 な問題で研究課題としたい。 